\begin{tabular}{|c|c|c|c|}
\hline K I N E R J A 15 (2), 2018 45-56 \\
feB UnMUL
\end{tabular}

\title{
Akuntabilitas pengelolaan keuangan organisasi keagamaan
}

\author{
Meriska Sari $^{1}$, Sri Mintarti ${ }^{2}$, Yunita Fitria $^{3}$ \\ Fakultas Ekonomi dan Bisnis Universitas Mulawarman, Samarinda. \\ ${ }^{1}$ Email: meriska.sari08@gmail.com \\ ${ }^{2}$ Email: sri.mintarti@feb.unmul.ac.id \\ ${ }^{3}$ Email: yunita.fitria@feb.unmul.ac.id
}

\begin{abstract}
Abstrak
Penelitian ini merupakan penelitian kualitatif yang bertujuan unuk mengetahui praktik akuntabilitas pengelolaan keuangan pada Masjid Baburrahmah, Samarinda. Data penelitian ini merupakan hasil dari pengamatan di lapangan, melalui wawancara pada 6 informan yang berkaitan dengan Masjid Baburrahmah, yaitu: ketua masjid, wakil ketua masjid, sekretaris masjid, bendahara masjid, dan 2 orang jama'ah masjid yang sering datang dan beribadah di masjid. Teori yang digunakan adalah Sharia'te Enterprise Theory (SET), Konsep Akuntabilitas berbasis Keadilan, dan Clash of Jurisdictional Theory. Metode penelitian yang digunakan adalah studi kasus. Penelitian ini menggunakan metode analisis data oleh Miles and Huberman untuk menganalisis data kualitatif. Metode analisis ini dilakukan dengan cara: (1) Pengumpulan data, (2) Reduksi data, (3) Penyajian data, dan (4) Penarikan kesimpulan. Hasil penelitian menunjukkan bahwa dalam akuntabilitas pengelolaan keuangan masjid terdapat nilai-nilai spiritualitas, seperti: kejujuran, adil, dan tanggungjawab yang mempengaruhi adanya praktik akuntabilitas dalam masjid Baburrahmah, baik dalam pengelolaan keuangan ataupun dalam hal memakmurkan masjid. Namun dalam penelitian ini menemukan pula bahwa praktik akuntansi yang masih kurang dan tidak sesuai dengan standar pencatatan dan pelaporan bagi entitas nirlaba, seperti organisasi keagamaan. Hal ini karena pengurus yang memiliki profesi yang berbeda dengan tanggungjawab yang diterima sehingga pemahaman pengurus mengenai akuntansi masih kurang.
\end{abstract}

Kata Kunci: akuntabilitas pengelolaan keuangan; clash of jurisdictional theory; konsep akuntabilitas berbasis keadilan; sharia'te enterprise theory

\begin{abstract}
This study is a qualitative research project that aims to better understand the accountability practices of financial management in the Baburrahmah Mosque, Samarinda. The research data was the result of observations in the field, through interviews with six informants related to Baburrahmah Mosque. They are: The head of Mosque, the Vice Head of Mosque, the Secretary of Mosque, the Treasurer of Mosque, and two people who are Jama'ah. The theories used are from Sharia'te Enterprise Theory (SET), the concept of accountability based on justice and the clash of jurisdictional theory. This research is a case study. This study uses the data analysis method by Miles and Huberman to analyze the qualitative data. This analysis method is done by the following steps. They are: (1) Data collection, (2) Data reduction, (3) Data display, (4) Conclusion drawing (verification). The result showed that when it comes to financial management accountability in a mosque, there are spiritual values such as honesty, fairness, and responsibility which had an influence on the practice of accountability in the Baburrahmah mosque, either in financial management or the promotion of the mosque. However, this research found that the accounting practices were not compatible to the standard of accounting for a non-profit enterprise such as a religious organization. It was because the people tasked with the responsibility of managing the mosque had different skills that are different from their responsibilities, therefore their understanding of accounting practices was lacking.
\end{abstract}

Keywords: accountability of financial management; clash of jurisdictional theory; concept of accountability based on justice; sharia'te enterprise theory 


\section{PENDAHULUAN}

Perkembangan ilmu akuntansi di Indonesia saat ini terus meningkat seiring dengan peningkatan kebutuhan manusia yang kompleks dan tuntutan perkembangan zaman. Ilmu akuntansi saat ini tidak hanya digunakan sebatas kegiatan pencatatan, pengungkapan, dan pelaporan laporan keuangan pada perusahaan, melainkan berkembang ke ranah yang lebih luas. Ilmu akuntansi yang berkembang pada lingkup yang lebih luas tidak hanya mencakup pemerintahan, namun hingga ke organisasi-organisasi masyarakat yang ada pada saat ini, seperti organisasi keagamaan. Indonesia yang merupakan negara yang beragama tentu memiliki organisasi-organisasi keagamaan yang berkembang dengan baik

Namun dalam perkembangan tersebut masih banyak tantangan, seperti kemungkinan terjadinya korupsi, penipuan, dan skandal manipulasi. Menurut Greenlee, et al (2007) yang dikutip oleh Fitria (2017), tantangan-tantangan ini tidak hanya dihadapi oleh organisasi nirlaba, tetapi juga oleh nonprofit dan organisasi keagamaan. Hal ini dibuktikan dengan Laporan 2012 Marquet pada Penggelapan di Amerika Serikat, yang menyatakan bahwa organisasi non-profit dan organisasi keagamaan memiliki sekitar seperdelapan dari seluruh insiden penggelapan utama. Skandal ini telah menunjukkan nonprofit dan organisasi keagamaan kurang transparansi dan akuntabilitas keuangan (Dhanani dan Connolly, 2012). Sedangkan, menurut Dewi, dkk (2015), Akuntabilitas dalam pengelolaan keuangan organisasi merupakan hal yang paling dituntut oleh para stakeholder.

Akuntabilitas dapat didefinisikan sebagai menuntut dan memberikan account, dimana menuntut adalah dari pihak kepala sekolah (manajemen) dan pemberian adalah tanggung jawab agen (masyarakat dan organisasi) (Roberts dan Scapens, 1985) yang disadur oleh (Fitria, 2017). Akuntabilitas ditunjukkan oleh individu dan organisasi tindakan tidak hanya melalui pelaporan dan pengungkapan persyaratan, tetapi juga dalam tanggungjawab mereka kepada publik dalam hal nilainilai organisasi dan kinerja (Ebrahim, 2003). Menurut Standbury (2003) dalam Mardiasmo (2006) menjelaskan pula, "Akuntabilitas dapat diartikan sebagai bentuk kewajiban mempertanggungjawabkan keberhasilan atau kegagalan pelaksanaan misi organisasi dalam mencapai tujuan sasaran yang telah ditetapkan sebelumnya melalui suatu media pertanggungjawaban yang dilaksanakan secara periodik".

Akuntabilitas pada organisasi non-profit hingga saat ini masih di dominasi oleh rasionalisasi hubunga principal-agent (Ebrahim 2003, Van Slyke 2007) yang memperlihatkan bahwa agent sebagai pihak ketiga diberi wewenang oleh principal untuk mengelola organisasi dan berpihak kepada kepentingan principal. Hubungan principal-agent timbul karena adanya pemisahan antara pemilik modal (principal) dan pengelolaan modal (agent). Pemisahan ini memicu adanya konflik kepentingan antara principal dan agent, hal ini disebabkan karena sejatinya manusia memiliki kecenderungan untuk mengutamakan kepentingan pribadi. Namun hal tersebut berbeda dengan yang ada di korporasi, menurut Siskawati, dkk (2016) kesalahan dalam pengelolaan dana donasi, tidak menimbulkan komplain dari donatur terhadap agent organisasi non-profit termasuk didalamnya adalah organisasi masjid.

Organisasi masjid dalam hal ini merupakan salah satu dari organisasi keagamaan. Masjid merupakan organisasi non-profit dimana pengurus masjid berfungsi sebagai agent yang berkewajiban mengatur dan melaporkan penggunaan dana yang diberikan oleh principal (Siskwati, dkk, 2016). Namun kritik terhadap akuntabilitas masjid mengatakan bahwa pengendalian internal dan pengawasan pengelolaan keuangan pada organisasi masjid masih lemah (Mohamed et al, 2014). Hal ini dikaitkan dengan kinerja masjid terhadap pengelolaan kegiatan masjid yang tidak efektif dan rendahnya profesionalitas pengurus dalam hal tata kelola (Yasmin et al, 2014).

Hal yang serupa juga disampaikan oleh Fitria (2017) yang menjelaskan, "Masjid adalah tempat dimana agama tumbuh sehingga ada komunitas Muslim yang memiliki kegiatan di masjid. Dengan demikian, kegiatan harus memberikan pertanggungjawaban kepada masyarakat". Pertanggungjawaban tersebut bersifat mandatory, karena masjid merupakan salah satu entitas yang menggunakan dana dari masyarakat sebagai sumber keuangan dan pemasukan, baik dalam bentuk infaq, sedekah, dan atau bentuk bantuan sosial lainnya yang diberikan masyarakat, sehingga masjid yang dapat dikatakan pula sebagai entitas publik maka semua aktivitasnya perlu dipertanggungjawabkan kepada publik.

Meskipun demikian, praktik akuntabilitas belum terlaksana sesuai dengan semestinya. Hal ini nampak pada fenomena yang ada di organisasi keagamaan, dalam hal ini penulis mengkhususkan pada Masjid Baburrahmah di wilayah Perumahan Griya Mukti Sejahtera (Perum GMS), Samarinda. Masjid Baburrahmah dipilih sebagai objek dalam penelitian karena dilatarbelakangi oleh kondisi dan karakter 
kebudayaan islam yang masih terlihat jelas di wilayah perumahan, dimana daerah perumahan sebagai instrumen modern yang seringkali tidak berbaur dalam masyarakat.

Dalam penelitian ini ditemukan adanya fakta di lapangan yang menunjukkan bahwa pengurus masjid, khususnya bendahara masjid yang merupakan pengelola keuangan masjid bukan dari seorang yang berlatarbelakang pendidikan akuntansi, melainkan warga sekitar masjid yang ditunjuk secara sukarela untuk menjadi pengurus masjid. Kemudian, dalam pengelolaan keuangan tidak adanya kejelasan secara mendetail dan terperinci mengenai bentuk pertanggungjawaban pengurus masjid dalam mengelola keuangan masjid. Sumber dana masjid yang umumnya diperoleh dari para jama'ah yang beribadah di masjid tersebut tidak dapat diketahui secara jelas penggunaan dana tersebut diperuntukkan untuk apa saja. Bendahara masjid hanya menggunakan sistem pencatatan sederhana dengan mencatat pemasukan dan pengeluaran, yang kemudian total pemasukan dan pengeluaran hanya disampaikan pada setiap jum'at tanpa adanya rincian secara jelas terkait penggunaan dana masjid tersebut.

Dari temuan tersebut dapat disimpulkan bahwa secara praktis, Masjid Baburrahmah telah melaksanakan pelaporan keuangan melalui pembacaan total saldo keuangan masjid pada setiap salat jum'at. Namun, hal tersebut tentu tidak dapat dijadikan suatu acuan sepenuhnya bahwa praktik akuntabilitas masjid Baburrahmah telah berjalan dengan baik dan benar. Sebagai entitas keagamaan tentu praktik akuntabilitas harus memperhatikan beberapa aspek-aspek spiritual disamping tetap memperhatikan kewajiban akan pertanggungjawaban penggunaan dana kepada masyarakat (jama'ah), selaku stakeholder dalam organisasi ini.

Praktik akuntansi dan akuntabilitas pada lembaga keagamaan atau lembaga nirlaba memang masih dianggap sesuatu yang tidak lazim. Walapun tidak lazim, penelitian terhadap praktik akuntansi pada lembaga keagamaan seperti gereja banyak dilakukan oleh beberapa peneliti akuntansi (Simanjuntak dan Januarsi, 2011). Seperti penelitian yang dilakukan oleh Dewi, dkk (2015) menyimpulkan bahwa proses pengelolaan keuangan GKBI dijamin oleh penerapan sistem akuntansi berbasis teologi dan melibatkan tenaga professional dalam pengelolaan keuangan Gereja Pusat. Sistem pengelolaan dibagi menjadi dua, yaitu pengelolaan keuangan uang persembahan/kurban dan pengelolaan keuangan dana sosial. Kemudian penelitian yang dilakukan oleh Randa, dkk (2011) yang menyimpulkan, Akuntabilitas spiritual pada organisasi Gereja Katolik memberikan makna pada komunitas gereja untuk menjaga hubungan vertikal dan horizontal. Rini (2015) dalam penelitiannya menyimpulkan pula bahwa akuntabilitas dalam organisasi gereja bukan hanya sebagai kebutuhan namun lebih pada jati diri gereja dalam membangun hubungan antara jemaat dan yang Maha Kuasa.

Penelitan lain yang berkenaan dengan konsep akuntabilitas terhadap organisasi keagamaan dijelaskan melalui penelitian dengan objek Masjid. Fitria (2017) menyimpulkan kerangka akuntabilitas menggambarkan bahwa bentuk-bentuk pertanggunjawaban (akuntabilitas formal dan informal) disusun untuk mencapai akuntabilitas kepada Allah. Oleh karena itu, timbal balik (reciprocalness) dari dua bentuk akuntabilitas memimpin manusia sebagai khilafah Allah untuk memenuhinya akuntabilitas kepada masyarakat dan Allah SWT. Singkatnya, manusia melakukan akuntabilitas mereka sebagai bagian dari ibadah kepada Allah SWT. Kemudian Salle dan Lutfillah (2014) dalam penelitan mengenai Akuntabilitas perspektif Islam menyimpulkan bahwa makna yang dapat diperoleh dari nilai keadilan dalam mempertanggungjawabkan amanah adalah bahwa setiap manusia harus mempertanggungjawabkan amanah dalam bentuk apa pun yang telah diberikan oleh pemberi amanah. Hal yang dapat dirasakan adalah pertanggungjawaban yang seadil-adilnya terhadap amanah adalah sebagai wujud penghambaan diri kepada Allah swt.

Berdasarkan latar belakang di atas, maka penulis merumuskan penelitian: Bagaimana praktik akuntabilitas pengelolaan keuangan Masjid Baburrahmah, Samarinda? Sedangkan tujuan penelitian yang ingin dicapai dalam penelitian ini adalah: Untuk mengetahui bagaimana praktik akuntabilitas pengelolaan keuangan pada Masjid Baburrahmah, Samarinda. Manfaat Penelitian ini terbagi kedalam dua bagian, yaitu

\section{Manfaat Teoretis}

Untuk menambah pengetahuan dan wawasan penulis mengenai praktik akuntansi dan akuntabilitas pada suatu organisasi keagamaan, yaitu masjid. Dan dengan menerapkan beberapa teori akuntansi yang diperoleh dalam perkuliahan. 
Sebagai kontribusi ilmiah, dengan menambah wawasan, pengetahuan dan sebagai referensi bagi civitas akademika lainnya untuk kemungkinan penelitian lebih lanjut mengenai topik-topik penelitian yang berkaitan baik yang bersifat melengkapi ataupun lanjutan.

Sebagai bahan perbandingan untuk penelitian-penelitian selanjutnya.

\section{Manfaat Praktis}

Melalui penelitian ini dapat menemukan suatu bentuk akuntabilitas dalam pengelolaan keuangan yang sesuai dengan kebutuhan masjid tersebut.

Sebagai referensi pemerintah untuk membuat suatu kebijakan atau regulasi berkenaan dengan akuntabilitas masjid.

\section{Kajian Pustaka}

\section{Akuntansi dan Akuntabilitas}

Akuntansi merupakan alat komunikasi yang penting bagi pihak-pihak yang berkepentingan seperti para investor, pemerintah, kreditur serta masyarakat yang membutuhkan informasi mengenai keuangan suatu organisasi atau entitas. Dalam dunia akuntansi banyak dikenal mengenai konsepkonsep dasar mengenai definisi akuntansi yang dikemukakan oleh pakar-pakar akuntansi. Berikut ini diuraikan beberapa definisi akuntansi menurut para ahli:

Menurut Rudianto (2009:4) Akuntansi adalah sebuah sistem informasi yang menghasilkan informasi keuangan kepada pihak-pihak yang berkepentingan mengenai aktivitas ekonomi dan kondisi suatu perusahaan.

Definisi akuntansi yang dikeluarkan oleh American Institute of Certified Public Accountans (AICPA) menjelaskan, "Akuntansi adalah suatu kegiatan jasa. Fungsinya adalah menyediakan data kuantitatif, terutama yang mempunyai sifat keuangan, dari kesatuan usaha ekonomi yang dapat digunakan dalam memilih alternatif-alternatif dari suatu keadaan".

Berdasarkan beberapa pendapat yang telah dikemukakan diatas, maka dapat diambil kesimpulan bahwa akuntansi adalah suatu tahapan dari proses pengidentifikasian, pencatatan, penggolongan, peringkasan, dan pelaporan data keuangan yang bersifat kuantitatif yang hasilnya digunakan sebagai informasi mengenai keadaan suatu keuangan atau ekonomi suatu entitas atau organisasi kepada pihakpihak yang membutuhkan.

Dalam ilmu akuntansi aspek yang perlu diperhatikan selain transparansi atas hasil pencatatan keuangan suatu entitas atau organisasi adalah akuntabilitas. Akuntabilitas dapat didefinisikan dari beberapa aspek, yaitu dari segi konsep, prinsip dan tanggungjawab. Akuntabilitas dari segi konsep oleh Lawton dan Rose yang dijelaskan Suherman (2007) yang mengatakan bahwa akuntabilitas sebagai sebuah proses dimana seorang atau kelompok orang diperlukan untuk membuat laporan aktivitas mereka dan dengan cara yang mereka sudah atau belum ketahui untuk melaksanakan pekerjaan mereka. Lessinger yang dijelaskan oleh Suherman (2007) menjelaskan pula bahwa akuntabilitas adalah kajian hubungan antara apa yang sudah dilakukan sekolah dengan dana yang digunakan dengan hasil belajar yang diperoleh.

Dari segi tanggungjawab, Menurut Mardiasmo (2006:3) menjelaskan akuntabilitas merupakan sebagai bentuk kewajiban mempertanggungjawabkan keberhasilan atau kegagalan pelaksanaan misi organisasi dalam mencapai tujuan dan sasaran yang telah ditetapkan sebelumnya, melalui suatu media pertanggungjawaban yang dilaksanakan secara periodik.

Sedangkan menurut Standar Akuntansi Pemerintah (SAP) tahun 2005, Akuntabilitas adalah mempertanggungjawabkan pengelolaan sumber daya serta pelaksanaan kebijakan yang dipercayakan kepada entitas pelaporan dalam mencapai tujuan yang telah ditetapkan secara periodik.

Dari beberapa pengertian mengenai akuntabilitas yang telah dijelaskan di atas dapat disimpulkan bahwa akuntabilitas merupukan suatu bentuk dari pertanggungjawaban dari suatu entitas terhadap tanggungjawab yang diperoleh, khususnya dalam mengelola keuangan suatu entitas atau organisasi yang biasanya digunakan oleh pengguna informasi keuangan entitas yang berasal dari eksternal entitas tersebut. Akuntabilitas juga merupakan hal yang menjadi tolak ukur akan keberhasilan dari tujuan dan pencapaian cita-cita entitas atau organisasi tertentu.

Hasil dari akuntansi adalah laporan keuangan. Pada dasarnya pembuatan laporan keuangan adalah suatu bentuk kebutuhan transparansi yang merupakan syarat pendukung adanya akuntabilitas yang berupa keterbukaan atas aktivitas pengelolaan keuangan sumber dana publik (Mardiasmo, 2006). 
Sehingga dapat dikatakan bahwa adanya akuntabilitas yang baik sejalan dengan praktik akuntansi yang baik dan benar. Hal ini karena tujuan praktik akuntansi yang sesuai dengan pedoman salah satunya adalah untuk menghasilkan (output) laporan keuangan yang baik. Laporan keuangan yang baik akan menunjukkan tingkat akuntabilitas suatu entitas yang baik.

\section{Pelaporan Keuangan Organisasi Non-Profit}

Pelaporan keuangan menurut Pernyataan Standar Akuntansi Keuangan Nomor 45 tentang pelaporan keuangan entitas nirlaba atau dalam hal ini termasuk didalamnya organisasi keagamaan, seperti masjid, komponen laporan keuangan nirlaba terdiri dari laporan posisi keuangan, laporan aktivitas, laporan arus kas, dan catatan atas laporan keuangan atau yang biasa disingkat CALK. Empat jenis laporan keuangan ini memiliki fungsi masing-masing. Bagi pihak eksternal hal ini akan memberikan gambaran berupa kegiatan operasi suatu entitas, bagi pemberi sumbangan dana masjid dimana hal ini juga merupakan bentuk pertanggungjelasan terkait penggunaan dana masjid.

\section{Akuntabilitas Publik dalam Entitas Keagamaan}

Definisi akuntabilitas publik menurut Mahmudi (2005) adalah kewajiban penerima tanggungjawab untuk mengelola sumber daya, melaporkan, dan mengungkapkan segala aktivitas dan kegiatan yang berkaitan dengan penggunaan sumber daya publik kepada pihak pemberi mandat (principal). Akuntabilitas publik juga dapat diartikan sebagai kewajiban pihak pemegang amanah untuk memberikan pertanggungjawaban, menyajikan, melaporkan dan mengungkapkan segala aktivitas dan kegiatan yang menjadi tanggungjawabnya kepada pihak yang memberikan amanah (Renyowijoyo, 2010). Berdasarkan beberapa definisi tersebut dapat disimpulkan bahwa akuntabilitas publik adalah bentuk pertanggungjawaban dari penerima atau pelaksana tugas (agent) berupa laporan atas segala aktivitas yang telah dilaksanakan kepada pemberi tugas (principal).

Akuntabilitas dapat dilihat sebagai salah satu elemen dalam responsibilitas. Akuntabilitas juga berarti kewajiban untuk mempertanggung jawabkan apa yang telah dilakukan atau tidak dilakukan oleh seseorang. Sedangkan responsibilitas merupakan akuntabilitas yang berkaitan dengan kewajiban menjelaskan kepada orang/pihak lain yang memiliki kewenangan untuk meminta pertanggungjawaban dan memberi penilaian (Simanjuntak dan Junarsi, 2011).

Entitas keagamaan tersebut seperti: Masjid, Gereja, dan Vihara merupakan suatu perkumpulan atau organisasi yang termasuk dalam jenis organisasi non-profit. Namun demikian, Simanjuntak dan Junarsi (2011) menjelaskan bahwa tuntutan akuntabilitas harus diikuti dengan pemberian kapasitas untuk melakukan keleluasaan dan kewenangan. Akuntabilitas publik terdiri dari akuntabilitas vertikal dan akuntabilitas horizontal. Akuntabilitas vertikal merupakan akuntabilitas kepada otoritas yang lebih tinggi, sedangkan akuntabilitas horizontal adalah akuntabilitas kepada publik secara luas atau terhadap sesama lembaga lainnya yang tidak memiliki hubungan atasan dan bawahan. Dalam konteks entitas keagamaan, akuntabilitas vertikal merupakan bentuk pertanggungjawaban kepada Tuhan. Manusia diberi amanah untuk mengelola bumi berdasarkan keinginan Tuhan (the will of God) (Triyuwono:2003). Ini artinya, bahwa manusia memiliki kewajiban dan harus dipertanggungjawabkan kepada Tuhan. Kemudian, akuntabilitas horizontal dalam konteks keagamaan merupakan akibat dari hubungan antara agent (manajemen) kepada masyarakat (stakeholder) dan alam (universe) (Triyuwono:2003). Hubungan tersebut mengharuskan pertanggungjawaban kepada orang-orang yang terkait (stakeholder) dan alam sekitar (universe).

\section{METODE}

Metode analisis data pada penelitian ini menggunakan model analisis data Miles and Huberman. Miles and Huberman (1984) dalam Sugiyono (2012:246), mengemukakan bahwa aktivitas dalam analisis data kualitatif dilaksanakan secara interaktif dan berlangsung secara terus-menerus sampai tuntas, sehingga datanya sudah jenuh. Menurut Moleong (2004:280-281), "Analisis data adalah proses mengorganisasikan dan mengurutkan data ke dalam pola, kategori, dan satuan uraian dasar sehingga dapat ditemukan tema dan tempat dirumuskan hipotesis kerja seperti yang disarankan oleh data".

Langkah-langkah analisis data menurut model analisis Miles and Huberman (1992) adalah sebagai berikut:

Pengumpulan data (Data Collection), yaitu mengumpulkan data di lokasi penelitian dengan melakukan observasi, wawancara kepada para informan, dan dokumentasi dengan menentukan strategi 
pengumpulan data yang tepat dan untuk menentukan fokus maupun pendalaman data pada proses pengumpulan data berikutnya.

Reduksi data (Data Reduction), yaitu proses seleksi, pemfokusan, transformasi data kasar yang diperoleh dari penelitian secara langsung, dan diteruskan pada waktu pengumpulan data. Dalam mereduksi data, setiap peneliti akan dipandu oleh tujuan yang akan dicapai. Tujuan utama dari penelitian kualitatif adalah pada temuan. Oleh karena itu, jika peneliti dalam melakukan penelitian menemukan segala sesuatu yang dipandang asing, tidak dikenal, dan belum memiliki pola maka hal itulah yang dijadikan perhatian peneliti dalam melakukan reduksi data.

Penyajian data (data display), yaitu rangkaian organisasi informasi yang memungkinkan penelitian dilakukan. Dalam penyajian data dapat dilakukan dalam bentuk uraian singkat, bagan, hubungan antara kategori, flowchart, dan sejenisnya. Dalam hal ini Miles and Huberman (1984) menyatakan, "the most frequent form of display data for qualitative research data in the past has been narrative text". Yang paling sering digunakan untuk menyajikan data pada penelitian kualitatif adalah teks yang bersifat naratif.

Penarikan Kesimpulan/ Veifikasi (Conclusion Drawing/Verification), pada tahap ini sebagai verifikasi terhadap rumusan masalah. Kesimpulan awal (rumusan masalah) yang dikemukakan masih bersifat sementara, dan akan berubah bila tidak ditemukan bukti-bukti yang kuat yang mendukung pada tahap pengumpulan data berikutnya. Tetapi apabila kesimpulan yang dikemukakan pada tahap awal, didukung oleh bukti-bukti yang valid dan konsisten saat peneliti kembali ke lapangan mengumpulkan data, maka kesimpulan yang dikemukakan merupakan kesimpulan yang kredibel.

\section{Uji Validitas}

Uji validitas pada penelitian kualitatif berbeda dengan penelitian kuantitatif. Menurut Sugiyono (2012:267), dalam uji validitas kualitatif terdapat dua macam validitas penelitian, yaitu validitas internal dan validitas eksternal. Pada penelitian ini menggunakan uji validitas internal, yaitu validitas yang berkenaan dengan derajad akurasi desain penelitian dengan hasil yang dicapai (Sugiyono, 2012:268). Dalam uji validitas internal atau yang disebut juga uji kredibilitas data, dapat dilakukan salah satunya dengan cara "triangulasi". Menurut Wiliam (1986) yang dikutip oleh Sugiyono (2012:273), "Triangulation is qualitative cross-validation. It assesses the sufficiency of the data according to the convergence of multiple data sources or multiple data collection procedures". Triangulasi ini diartikan sebagai pengecekkan data berdasarkan dari berbagai sumber data atau berbagai prosedur pengumpulan data. Triangulasi merupakan teknik pengumpulan data yang bersifat menggabungkan dari berbagai teknik pengumpulan data dan sumber data yang telah ada.

Menurut Sugiyono (2012:241) bila peneliti melakukan pengumpulan data dengan triangulasi, maka sebenarnya peneliti mengumpulkan data yang sekaligus menguji kredibilitas data, yaitu mengecek kredibilitas data dari berbagai sumber data. Triangulasi teknik, berarti peneliti menggunakan teknik pengumpulan data yang berbeda-beda untuk mendapatkan data dari sumber yang sama (Sugiyono, 2012: 241). Peneliti menggunakan pengamatan (observasi), wawancara mendalam (deep interview), dan dokumentasi untuk sumber-sumber data yang sama secara serempak. Bentuk triangulasi teknik dapat digambarkan pada gambar 1. sebagai berikut:

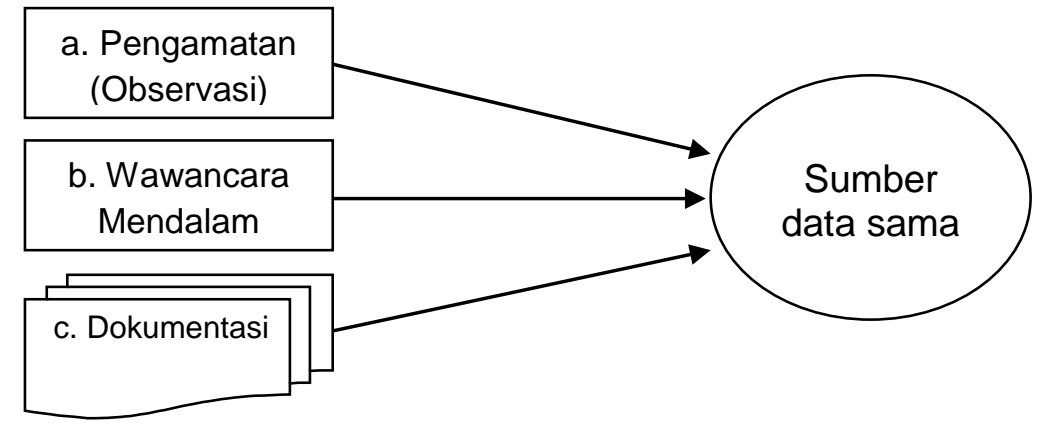

Gambar 1. Triangulasi "teknik" pengumpulan data

Sumber: Buku Metode Penelitian Kuantitatif, Kualitatif, dan R\&D oleh Sugiyono 2012 
Dalam triangulasi pada penelitian ini triangulasi sumber perolehan data digambarkan pada gambar 2 dan triangulasi prosedur pengumpulan data digambarkan pada gambar 3. sebagai berikut:

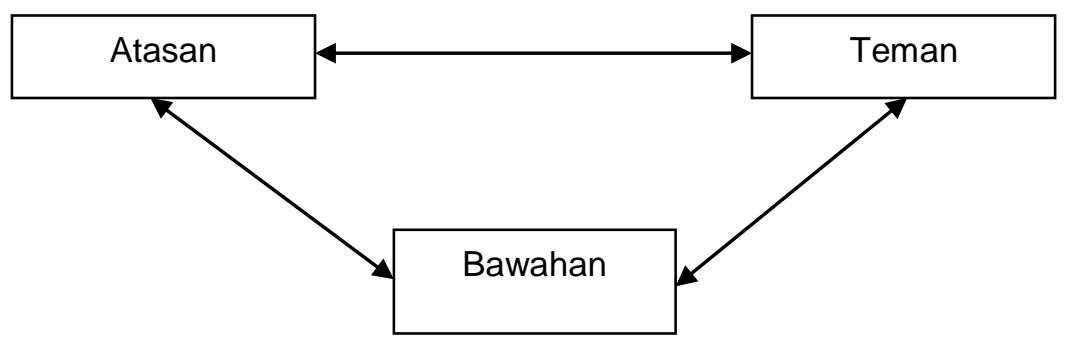

Gambar 2. Triangulasi Sumber Data Penelitian

Sumber: Buku Metode Penelitian Kuantitatif, Kualitatif, dan R\&D oleh Sugiyono 2012

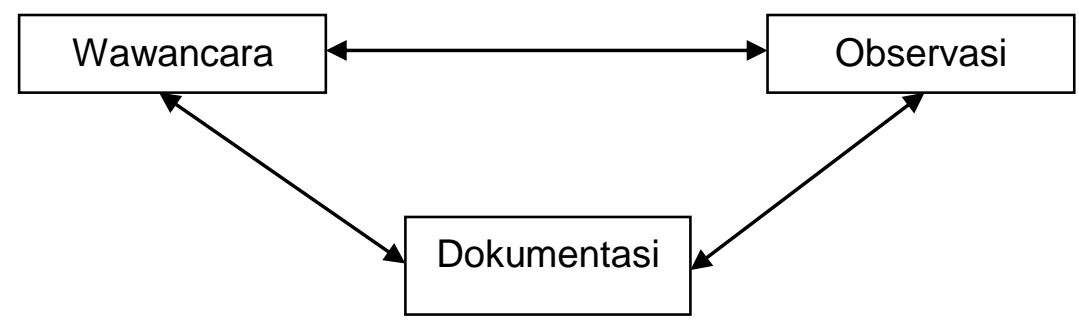

Gambar 3. Triangulasi Prosedur Pengumpulan Data Penelitian

Sumber: Buku Metode Penelitian Kuantitatif, Kualitatif, dan R\&D oleh Sugiyono 2012

\section{HASIL DAN PEMBAHASAN}

\section{Praktik Akuntansi yang Masih Sederhana dalam Masjid Baburrahmah}

Dalam analisis praktik akuntansi pada Masjid Baburrahmah secara umum sudah terlaksana, meskipun dengan pemahaman dari pengurus yang masih kurang dan masih memaknai akuntansi sebatas kebutuhan wajib bagi organisasi profit. Hal ini sama seperti temuan pada penelitian terdahulu oleh Fitria (2017) yang menyatakan bahwa masjid komunitas memiliki kurangnya pengetahuan tentang akuntansi. Masjid Baburrahmah tergolong masjid komunitas karena dibangun dan dikelola dari warga sekitar yang membentuk komunitas atau kepengurusan sendiri. Praktik akuntansi pada masjid ini masih dilakukan cukup sederhana dan dan belum baku. Hal ini sesuai dengan pernyataan dari iforman S3 yang menerangkan:

"Kalau praktiknya kayaknya sih belum yah - maksudnya untuk akuntansi yang secara baku. Yah, yang akuntansi pencatatan sederhana aja yang kita gunakan."

Dari jawaban informan mengenai praktik akuntansi pada masjid Baburrahmah secara eksplisit menerangkan bahwa praktik akuntansi belum terlaksana secara menyeluruh dan terlihat jelas. Akuntansi yang baku dalam hal ini dimaknai bahwa praktik akuntansi tidaklah dilakukan secara menyeluruh melainkan hanya sebatas kebutuhan pencatatan kas masuk dan kas keluar. Hal ini kemudian disampaikan oleh informan J5 dari pihak eksternal pengurus yang memperkuat pernyataan sebelumnya:

"Yang saya tahu sih. paling itu hanya catatan, catatan mingguan Sederhana aja. Pokoknya yang biaya keluar dicatat, biaya yang masuk dicatat itu disesuaikan aja catatan-catatan itunya.. datanya."

Dari pernyataan-pernyataan tersebut menggambarkan bahwa praktik akuntansi pada masjid masih hanya sebatas pencatatan keuangan yang sederhana, teratur yang dilaksanakan setiap minggu, dan masih belum baku atau sesuai standar yang berlaku. Begitu pula dengan informan-informan lainnya, mereka berpendapat bahwa pencatatan keuangan pada Masjid Baburrahmah masih sederhana.

Sedangkan dalam Pernyataan Standar Akuntansi Keuangan nomor 45 tentang pelaporan keuangann entitas nirlaba diatur mengenai laporan yang perlu disajikan oleh pengurus masjid terdiri dari 4 jenis laporan keuangan, yaitu laporan posisi keuangan, laporan aktivitas, laporan arus kas, dan catatan atas laporan keuangan atau yang biasa disingkat CALK. Namun demikian, dalam masjid Baburrahmah pencatatan hanya terfokus pada kas masjid, tidak mencakup pencatatan aset-aset masjid yang bersifat moneter. Sehingga, sangat sulit untuk memodifikasi pencatatan keuangan masjid ke 
dalam empat jenis laporan keuangan yang sesuai dengan standar. Dari keempat jenis standar laporan tersebut yang dapat digunakan adalah laporan arus kas. Laporan kas menyajikan informasi mengenai penerimaan dan pengeluaran kas dalam satu periode, dalam hal ini modifikasi dapat dilakukan untuk periode satu bulan yaitu sesuai data penerimaan kas pada tanggal 12 Januari 2018 - 02 Februari 2018.

\section{Pengurus dan Jama'ah Saling Membantu dalam Pengelolaan Keuangan Masjid Baburrahmah}

Dalam pengelolaan keuangan, pengurus memiliki peran tidak hanya sebagai pelaksana melainkan peran pengurus dalam pelaksanaan pengelolaan keuangan adalah dengan melakukan kontrol atau pemantauan, sehingga hal-hal yang mungkin dapat menimbulkan kesalahan dapat diminimalisir. Kemudian hal tersebut diperjelas dengan pernyataan informan K1 berikut:

"Kita mengelola masjid bersama-sama aja. Artinya ndak ada ketua, seperti ndak ada ketua lah bersama-sama aja lah. Karena itu kan kita kerja amal sih yah."

Dari penjelasan informan tersebut menunjukkan bahwa dalam kepengurusan masjid dilaksanakan secara bersama-sama, dalam hal ini baik peran seorang ketua atau pengurus lain tidak membatasi diri untuk saling terbuka kepada yang lainnya, termasuk kepada jama'ah. Selain itu adanya pandangan bahwa mengurusi masjid merupakan pekerjaan amal atau pekerjaan secara sukarela sehingga pengurus cenderung menyampingkan adanya batasan-batasan dari tingkat jabatan atau amanah yang diterima. Pernyataan ini menggambarkan adanya nilai-nilai spiritualitas pengurus dalam melaksanakan tugas atau amanah mereka, seperti kerja ikhlas, dan bertanggungjawab. Hal ini secara tidak langsung mendukung adanya teori Sharia'te Enterprise dimana memiliki nilai-nilai syariah, seperti: kejujuran, ikhlas, dan bertanggungjawab.

Selanjutnya dari informan J6 menambahkan penjelasan tersebut:

“Kalau tiap Jum'at itu kan pengurus pada ngumpul. Yah maksudnya kita banyak itu juga biar transparan aja kan, jadi uang tuh gak ini lah.. saling percaya aja gitu kan. Jadi ngitungnya (pemasukan uang masjid) sama pak RT, pengurus masjidnya, sama orang-orang yang sering kesini (masjid) sering kumpul juga. Kan kalau sendirian juga kwalahan ngitung uangnya."

Pendapat dari informan dapat disimpulkan bahwa dalam pengelolaan keuangan masjid dilakukan secara terbuka, yaitu pada setiap hari Jum'at dilakukan penghitungan penerimaan infaq dan sadaqah (salawatan) masjid oleh bendahara yang diawasi oleh pengurus-pengurus lainnya bersama masyarakat yang merupakan jama'ah masjid, termasuk pak Ketua RT setempat. Secara jelas hal tersebut menyatakan adanya transparansi dan akuntabilitas yang dilakukan oleh pengurus secara 'horizontal', yaitu dengan keterbukaan kepada seluruh jama'ah dan pengurus yang merupaka stakeholder.

Hal tersebut juga sesuai dengan penemuan pada penelitian terdahulu oleh Siskawati, dkk (2015) yang menemukan bahwa kepercayaan masyarakat merupakan faktor utama yang dipegang teguh oleh pengurus dalam menjalankan kegiatan dan program-program Masjid. Untuk menjaga kepercayaan masyarakat, pengurus Masjid selalu menjunjung nilai kejujuran yang ada pada dirinya. Cara yang dilakukan pengurus dan juga sebagai bentuk adanya nilai kejujuran adalah dengan mengajak jama'ah untuk bersama-sama menghitung pemasukan dan pengeluaran masjid.

\section{Pertanggungjawaban Pengelolaan Keuangan kepada Jama'ah Masjid Baburrahmah (Akuntabilitas Horizontal)}

Pertanggungjawaban atas pengelolaan keuangan yang dilaksanakan oleh pengurus kepada jama'ah selaku stakeholder masjid merupakan bentuk dari Akuntabilitas Horizontal. Akuntabilitas horizontal merupakan bentuk pertanggungjawaban kepada pihak lain yang kedudukannya sama, namun memiliki hak untuk mengetahui hasil pengelolaan keuangan tersebut. Akuntabilitas horizontal pada masjid Baburrahmah diimplementasikan dengan cara membacakan total hasil penerimaan, rincian-rincian pengeluaran dana masjid yang telah terpakai, dan saldo akhirnya setiap hari Jum'at kepada seluruh jama'ah masjid Baburrahmah. Hal ini dengan jelas disampaikan oleh informan J5 yang merupakan salah satu jama'ah masjid Baburrahmah:

“Iya. Setiap Jum'at ada penyampaian untuk biayanya. Minimal itu pengurus masjid menyampaikan dana yang masuk, baik itu berupa infaq dari kotak amal, ataupun mungkin ada yang kayak misalnya memberikan sajadah atau Al-Qur'an itu sih yang disampaikan."

Penjelasan informan menerangkan bahwa bentuk pelaporan dan pengungkapan keuangan masjid dilaksanakan setiap Jum'at, dimana setiap pemasukan yang diterima secara langsung oleh pengurus 
dan penerimaan dari Jum'at lalu dibacakan didepan jama'ah masjid. Dari pernyataan tersebut pula secara tidak langsung membuktikan adanya temuan pada penelitian terdahulu oleh Simanjuntak dan Junarsi (2011) yang mengatakan bahwa sejatinya akuntansi dalam prakteknya mendorong transparansi dan akuntabilitas bergeser menjadi instrumen yang mendorong perilaku ibadah yang "riya", atau yang dikenal dengan istilah pamer. Indikasi perilaku ibadah yang "riya" terjadi secara tidak sengaja karena adanya keharusan dari pengurus untuk menyampaikan dana-dana sumbangan yang diterima masjid dari para donatur.

Selanjutnya, bentuk pertanggungjawaban pengelolaan keuangan dan keterbukaan kepada jama'ah masjid selaku stakeholder dijelaskan pula oleh informan J6 sebagai berikut:

"Yah disampaikan Jum'at itu aja. Setiap Jum'at itu disampaikan, bahwa pendapatan minggu kemarin itu sekian, bahwa pengeluaran minggu kemarin sekian. Kalau isi laporannya sih yang dibacakan itu: laporan keuangan, sumbangan-sumbangan dari masyarakat yang minta dibacakan do'a (Al-Fatihah), sama uang shalawat Jum'at lalu, pengeluarannya apa aja dari Jum'at lalu sampai Kamis kemarin. Pokoknya yang per minggu - per minggu gitu. Setelah itu ditulis di papan keuangan di masjid. Jadi setiap Jum'at apa yang dilaporkan itu juga yang ada di papan pengumuman."

Dari penjelasan jawaban diatas menunjukkan bahwa bentuk akuntabilitas dan transparansi kepada para jama'ah selaku stakeholder masjid Baburrahmah adalah dengan melaporkan setiap pada saat salat Jum'at dan di cantumkan lagi pada papan laporan keuangan di Masjid Baburrahmah agar setiap jama'ah dapat melihatnya.

Bentuk akuntabilitas ini juga membuktikan teori SET dimana dalam teori ini stakeholder meliputi direct participants dan indirect participants. Direct participants yaitu mereka yang memiliki kontribusi langsung terhadap masjid, seperti: donatur, atau pengurus masjid. Sedangkan, indirect participants adalah pihak yang sama sekali tidak memberikan kontribusi kepada masjid, baik dari segi keuangan maupun tenaga, seperti: musafir.

Praktik akuntabilitas yang dilakukan pengurus masjid kepada para stakeholder dengan menyampaikan hasil laporan keuangan masjid di papan informasi yang dapat dilihat oleh semua orang yang datang ke masjid, baik itu jama'ah yang memberikan infaq dan sadaqah kepada masjid, pengurus-pengurus masjid yang ingin melihat perkembangan keuangan masjid, dan orang-orang yang datang dari wilayah lain untuk beribadah di masjid tersebut (musafir) dapat melihat dari adanya bentuk akuntabilitas atau pertanggungjawaban yang disampaikan oleh pengurus kepada semua orang.

\section{Kerja Ikhlas dalam Menjalankan Tanggungjawab dan Memakmurkan Masjid sebagai bentuk Amanah (Akuntabilitas Vertikal)}

Dalam menerima dan menjalankan amanah, pengurus memiliki tanggungjawab untuk menjaga masjid, artinya sebagai pengurus masjid yang menerima amanah berusaha untuk memfungsikan masjid sesuai dengan yang seharusnya, tanpa ada kepentingan-kepentingan dari golongan tertentu. Meskipun masjid merupakan tempat untuk berkumpul, namun dalam hal ini pengurus membatasi untuk masuknya pengaruh politik yang memiliki kepentingan-kepentingan tertentu. Hal ini berbeda dengan temuan pada penelitian yang dilakukan oleh Fitria (2017) yang menerangkan bahwa masjid memiliki pengaruh politik dalam mendukung mekanisme akuntabilitas. Dimana hal tersebut menyebabkan masjid memperoleh dana untuk kegiatan keagamaan.

Kemudian dalam melaksanakan amanahnya, pengurus berusaha untuk menjalankan dengan kerja ikhlas hal ini dijelaskan oleh informan W2 yang memaparkan pendapatanya lebih jelas:

"Yah kita berupaya untuk memakmurkan masjid. Kita yah berupaya untuk mengajak masyarakat untuk pergi ke masjid terutama yang laki-lakinya kan. Karena laki-laki yag saleh itu adalah yang salat wajibnya di masjid. Jadi kita harus bisa membangun kesadaran itu melalui ceramahceramah khatib yang kita pesan kepada para khatib. Kemudian kita juga berupaya mengajak masyarakat itu, setelah $b a^{\prime} d a$ maghrib itu jangan pulang, dimasjid lah.. mau ngapain kah.. mau ngaji kah, mau dzkir kah, terserah. Yah itu sih sebagai bentuk tanggungjawab kita. Kalau bentuk pertanggungjawaban keuangan itu disampaikan ke masyarakat, kalau pertanggungjawaban dari kegiatan (sebagai pengurus) itu yah kita berusaha istiqomah, mengajak mereka. Karena Allah itu kan menilai bukan dari hasil tapi dari upaya kita. Yah walaupun tidak ada hasilnya (digaji)."

Dari pemaparan mengenai bagaimana informan selaku pengurus berusaha menjalankan amanah yang diterima dan mempertanggungjawabkan hal tersebut dengan cara kerja ikhlas dan terus istiqomah mengajak masyarakat untuk memakmurkan masjid, sebagai tugas utama mereka sebagai hamba yang 
beriman kepada Allah SWT. Hal ini merupakan bentuk akuntabilitas 'vertikal', yaitu adanya bentuk tanggungjawab yang dimiliki pengurus kepada Allah SWT untuk tidak hanya mengawasi dan mengawal kegiatan pengelolaan keuangan, tetapi juga tanggungjawab untuk memenuhi dan memakmurkan masjid agar tetap 'hidup'. Hal ini mendukung teori SET dimana adanya konteks akuntabilitas yang berpusat pada Khalifatullah fil Ardh, yaitu akuntabilitas yang berpusat pada $a b d$ ' Allah. Akuntabilitas ini merupakan bentuk pertanggungjawaban berhubungan ketundukan seorang hamba terhadap ketetapan syari'ah. Akuntabilitas ini merupakan akuntabilitas secara vertikal dimana berhubungan langsung dengan Allah SWT.

Selanjutnya, kerja ikhlas dalam pengurus juga karena dalam kegiatan kepengurusan masjid pengurus melaksanakannya tanpa digaji. Hal tersebut menyebabkan sulitnya dalam mengukur kinerja, karena dalam melaksanakan tanggungjawab semata-mata dilaksanakan karena Allah SWT. Pernyataan ini sesuai dengan temuan dalam penelitian sebelumnya yang dilakukan oleh Siskawati, dkk (2015) yang mengatakan bahwa, akuntabilitas memiliki sejumlah tantangan, salah satunya adalah tidak adanya hukum dan aturan formal yang mewajibkan organisasi untuk menyiapkan laporan kinerja.

Hal ini karena dalam konteks organisasi masjid, terkhususnya masjid komunitas cenderung tidak memiliki sistem aturan yang berlaku secara mengikat, melainkan hanya sebatas hukum sosial dan adanya nilai-nilai spiritualitas yang menjadi pembatas dalam melaksanakan tugas-tugasnya.

\section{Tanggungjawab Pengurus Tidak Sesuai dengan Pekerjaan atau Profesi Sesungguhnya}

Dari hasil analisis peneliti mengenai kesesuaian keahlian yang dimiliki pengurus dengan tanggungjawab yang diterima, khususnya dalam pengelolaan keuangan menemukan bahwa dalam konteks organisasi masjid kepercayaan masyarakat merupakan faktor utama yang dipegang teguh oleh pengurus dalam menjalankan kegiatan masjid. Temuan ini sekali lagi mendukung temuan pada penelitian terdahulu yang dilakukan oleh Siskawati, dkk (2015) yang menyatakan bahwa kepercayaan masyarakat merupakan faktor utama yang dipegang teguh oleh pengurus dalam menjalankan kegiatan dan program-program Masjid. Untuk menjaga kepercayaan masyarakat, pengurus Masjid selalu menjunjung nilai kejujuran yang ada pada dirinya.

Dari hasil penelitian ini peran akuntansi yang tidak konsisten pada Masjid Baburrahmah, Samarinda menunjukkan secara tidak langsung bahwa tidak terjadi Clash of Jurisdictional. Sistem pergantian kepengurusan masjid Baburrahmah yang dipilih melalui musyawarah oleh jama'ah masjid bersama-sama dengan pengurus yang lama atau yang masih menjabat dengan sistem sukarela dan menilai dari tingkat istiqomah calon pengurus untuk beribadah di masjid, mengabaikan tingkat pemahaman dan keahlian seseorang dalam bidangnya. Hal ini tersirat pada pernyataan dari informan S3 sebagai berikut:

"Kalau saya sih bagusnya begitu. Secara real harusnya gitu. Tapi sekarang ini yang jadi pengurus masjidnya ndak mau. Jadi sekarang ini yang ditunjuk juga karena yang tunjukkan dari masyarakat. Yang penting dia mau, terutama bendahara. Apalagi kita ini kan orang instansi pemerintahan kadang yah gak sesuai dengan job nya kita. Yah untung-untung lah kalau mau jadi pengurus."

Selain itu, karena kurangnya kebutuhan Sumber Daya Manusia (SDM) yang masih produktif dan ahli, seperti halnya mahasiswa, dan karena tingkat partisipasi masyarakat untuk memakmurkan masjid masih kurang. Hal ini dikarenakan faktor lingkungan masjid yang merupakan perumahan, sehingga masyarakat-masyarakat yang produktif lebih cenderung aktif dan berkarya di luar. Seperti pernyataan yang disampaikan oleh informan J6:

"Yah karena disini susahnya tadi itu.. karena orang disini kan orang-orang perumahan kan sibuk. Sibuk kerja semua, jadi yang aktif-aktif datang ke masjid itu kan yang ada itu-itu saja orangorangnya (mayoritas orang tua)."

Sehingga, pada keyataannya peran akuntansi pada masjid Baburrahmah tidak terealisasi dengan konsisten pada masjid ini. Kondisi lingkungan tersebut juga secara tidak langsung sebagai salah satu faktor kurang berkembangnya praktik akuntansi pada masjid Baburrahmah.

\section{SIMPULAN}

Berdasarkan hasil temuan dan pembahasan mengenai akuntabilitas pengelolaan keuangan pada Masjid Baburrahmah, Samarinda, maka dapat ditarik kesimpulan bahwa praktik akuntabilitas pada masjid sudah sesuai dengan Syari'ate Enterprise Theory (SET) yang dalam hal ini berada pada 
konteks organisasi keagamaan yang merupakan organisasi non-profit. Kemudian praktik akuntabilitas pada masjid sudah sesuai dengan Konsep Akuntabilitas berbasis Keadilan yang didalamnya terkandung 3 nilai-nilai akuntabilitas.

Hal ini dibuktikan dengan temuan adanya bentuk pertanggungjawaban dari pengelolaan masjid dengan membacakan laporan keuangan setiap salat jum'at dan menuliskannya pada papan informasi masjid mengenai perkembangan keuangan masjid. Kemudian pengelolaan keuangan yang dilaksanakan dengan jujur dan terbuka bersama pengurus masjid dan kepada jama'ah juga menunjukkan nilai-nilai akuntabilitas berbasis keadilan dilaksanakan dengan baik pada masjid tersebut. Selain itu, mengajak jama'ah untuk beribadah di masjid dan memakmurkan masjid merupakan bentuk lain dari pertanggungjawaban atas amanah yang diterima khususnya kepada Allah SWT.

Kemudian hasil penelitian menunjukkan pula bahwa praktik akuntansi pada Masjid Baburrahmah, Samarinda masih dilakukan dengan sederhana. Praktik akuntansi dimaknai hanya sebagai proses pengelolaan keuangan dengan pencatatan pemasukan - dan pencatatan pengeluaran. Hal ini terjadi karena adanya perbedaan perofesi sesungguhnya dari amanah yang diterima oleh pengurus, sehingga pemahaman mengenai akuntansi secara mendalam masih sangat kurang. Meskipun dalam praktik pengelolaan keuangan sudah dilakukan dengan sangat jujur, transparan dan amanah, namun praktik akuntansi dalam organisasi ini masih belum dilaksanakan dengan standar yang seharusnya. Selain itu, sistem pemilihan pengurus masjid yang dilakukan dengan musyawarah cenderung menunjuk dengan sukarela. Hal ini menunjukkan bahwa Clash of Jurisdictional pada pengurus masjid tersebut belum terjadi.

Dari simpulan tersebut peneliti memberikan saran untuk adanya perbaikan mengenai praktik pencatatan keuangan masjid, yaitu dengan mencatat penerimaan aset-aset non-kas masjid agar lebih terperinci dan transparan. Kemudian Peneliti selanjutnya diharapkan dapat meneliti lebih lanjut mengenai praktik terhadap akuntabilitas pengelolaan keuangan masjid-masjid yang ada di samarinda sehingga dapat dijadikan perbandingan dengan penelitian sebelumnya. Dan diharapkan pemerintah dapat membuat program berkaitan dengan pemberdayaan masjid-masjid, sehingga sumber dana bagi masjid dapat bertambah dan masjid dapat mengikuti standar pencatatan dan pelaporan akuntansi yang berlaku umum, yaitu PSAK 45 bagi organisasi keagamaan.

\section{DAFTAR PUSTAKA}

Dewi, K.G.S.S., Atmadja, A.W.T., dan Adiputra, M.P. 2015. Konsep Akuntabilitas Keuangan dalam Organisasi Keagamaan (Studi Kasus pada Gereja Kerasulan Baru di Indonesia, Distrik Jawa Timur dan Bali). Jurnal Akuntansi program S1 Vol. 3 No.1

Dhanani, A \& Connolly, C. 2012. Discharging not-for-profit accountability: UK charities and public discourse. Jurnal Accounting, Auditing \& Accountability Vol. 25 No.7

Ebrahim, A. 2003. Making Sense of Accountability: Conceptual Perspectives for Nothern and Southern Non Profits. Jurnal Non-profit Management and Leadership Vol. 14 No.2

Fitria, Yunita. 2017. Akuntabilitas pada Organisasi Religi: Studi Kasus Masjid-Masjid di Balikpapan, Kalimantan Timur. Jurnal Akuntabel Vol. 14 No.1

Institut Akuntan Publik Indonesia (IAPI). 2005. Standar Akuntansi Pemerintah (SAP). IAPI. Jakarta

Mardiasmo. 2006. Perwujudan Transparansi Akuntabilitas Publik Melalui Akuntansi. Penerbit Andi. Yogyakarta

Moleong, L. J. 2004. Metodologi Penelitian Kualitatif. Edisi Revisi. PT Remaja Rosdakarya. Bandung

Mohamed, I. S, N.H.A. Aziz, M.N. Masrek, dan N.M. Daud. 2014. Mosque Fund Management: Issues on Accountability and Internal Controls. Jurnal Precedia-Social and Behaviour Sciences Vol. 145 Hlm. 189-194.

Mulawarman, Aji Dedi. 2008. Akuntansi Syariah: Teori, Konsep dan Laporan Keuangan. Kreasi Wacana. Yogyakarta 
Randa, Fransiskus, Triyuwono, Iwan, Ludigdo, Unti, dan Sukoharsono, Eko. G. 2011. Studi Etnografi: Akuntabilitas Spiritual pada Organisasi Gereja Katolik yang Terinkulturasi Budaya Lokal. Jurnal Akuntansi Multiparadigma (JAMAL) Vol. 2 No.1

Rini, Ayu Dwidyah. 2015. Relevansi Sustainability, Accountability, Transparency Program Entrepreneurial University terhadap Sikap Komunitas Gereja. Jurnal Akuntansi Multiparadigma (JAMAL) Vol. 6 No. 5

Roberts, J., dan Scapens, R. 1985. Accounting Systems and Systems of Accountability Understanding Accounting Practices in Their Organisational Context.Acoounting, Organisations and Society.Hal 443-456

Rudianto. 2009. Pengantar Akuntansi. Erlangga. Jakarta

Salle, Ilham Z, dan Lutfillah, Novrida Q. 2014. Akuntabilitas Perspektif Islam. Akuntansi Syariah: Seri Konsep dan Aplikasi Ekonomi dan Bisnis Islam. FORDEBI \& ADESY. Jakarta

Simanjuntak, D. A, dan Junarsi, Yeni. 2011. Akuntabilitas dan Pengelolaan Keuangan di Masjid. Jurnal Simposium Nasional Akuntansi 14. Aceh

Siskawati, Eka, Ferdawati, dan Surya, Firman. 2015. Bagaimana Masjid dan Masyarakat Saling Memakmurkan? Pemaknaan Akuntabilitas Masjid. Jurnal Akuntansi Multiparadigma (JAMAL) Vol. 7 No.1

Sugiyono. 2012. Metode Penelitian Kuantitatif, Kualitatif, dan R\&D. Cetakan ke 17. Alfabeta. Bandung

Suherman, T. 2007. Masalah Hukum tentang Penerapan Good Coorporate Governance pada Dunia Usaha. Badan Pembinaan Hukum Nasional Departemen Hukum dan Hak Asasi Manusia RI. Jakarta

Triyuwono, Iwan. 2004. Formulasi Karakter Laporan Akuntansi Syari'ah dengan Pendekatan Filsafat Manunggaling Kawulo Gusti (Syekh Siti Jenar). Simposium Nasional Sistem Ekonomi Islam II. PPBEI, Universitas Brawijaya 